\title{
Teacher Expectations of Students' Classroom Behavior Across the Grade Span: Which Social Skills Are Necessary for Success?
}

KATHLEEN L. LANE

JOSEPH H. WEHBY

CRISTY COOLEY

Peabody College of Vanderbilt University

Aвstract: This study explored teachers' $(\mathrm{N}=717)$ expectations of student behavior along school level (elementary us. middle vs. high), program type (general us. special education), and school type (high risk vs. low risk). Results indicated that all elementary and middle school teachers shared similar views regarding the importance of self-control skills, whereas high school special education teachers viewed self-control skills as significantly more important than did high school general education teachers. High school teachers rated assertion skills as significantly less important relative to elementary or middle school teachers. Results also indicated that teachers at high-risk schools viewed self-control and assertion skills as more critical for success than did teachers at low-risk schools.

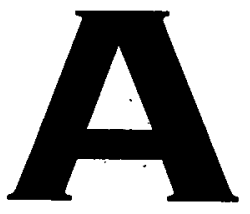

$s$ children and youth progress across the grade span, they are expected to meet teachers' expectations regarding academic performance, behavioral decorum, and social interactions. For example, teachers expect students to attend to and follow directions, make their assistance needs known in an appropriate fashion, ignore peer distractions when working, and manage conflicts with peers and adults (Hersh \& Walker, 1983; Kerr \& Zigmond, 1986; Lane, Pierson, \& Givner, 2003). Moreover, teachers of all students, kindergarten through 12th grade, expect students to demonstrate self-control and cooperation skills (Gresham, Dolstra, Lambros, McLaughlin, \& Lane, 2000; Lane, Givner, \& Pierson, 2004; Lane, Pierson, \& Givner, 2004). When students fail to meet these expectations, they are often at heightened risk. for a range of undesirable outcomes such as strained relationships with peers and adults, referrals to the school site disciplinarian, missed instructional time and content, referrals to the prereferral intervention process, and assignment to alternative settings (Fuchs et al., 1990; Lane, Mahdavi, \& Borthwick-Duffy, 2003). 
Furthermore, students who are nonresponsive to interventions generated by the prereferral intervention teams or who continue to be unsuccessful in meeting their teachers' expectations may be referred for assessment to determine special educational eligibility (Lane, Mahdavi et al.). Negative outcomes may also extend beyond the instructional setting including substance abuse, chaotic personal lives, and limited or absent postsecondary educational experiences (Edgar, 1992; Wagner, D’Amico, Marder, Newman, \& Blackorby, 1992). Thus, the consequences of not meeting teachers' expectations may result in a variety of pejorative outcomes within and beyond the school setting.

Although many students begin their early school experiences with the necessary skills and experiences that promote adaptive relationships with peers and adults, other students may be less prepared to meet teacher expectations for a variety of reasons. First, students may simply be unaware of teachers' expectations either because the teachers' expectations differ from parental expectations in the home setting or because teachers are unclear or inconsistent in reinforcing their expectations (Lane, Pierson, \& Givner, 2004). Second, teachers may not be aware of their own expectations for student behavior and that expectations vary across different groups of teachers (Brophy, 1986, 1996). Third, expectations may change as students progress through the grade levels, particularly as students transition from elementary to middle school (Blyth, Simmons, \& Carlton-Ford, 1983; Seidman, Allen, Mitchell, \& Feinman, 1994) and from middle to high school (Isakson $\&$ Jarvis, 1999). These transitions are characterized by an increased emphasis on independent learning and a heightened importance of peer relationships (Isakson \& Jarvis). Finally, expectations may be different at schools serving populations with varying degrees of risk or in communities with varying degrees of affluence (Walker, Ramsey, \& Gresham, 2004).

Given the negative outcomes porentially confronting students who fail to meet teachers' expectations and the fact that srudents may fail to meet teacher expectations for a variety of reasons, the requirements or expectations that teachers have for student behavior actoss the grade span need to be clearly understood. This information on teachers' expectations may be used in at least four ways. First, it may be used to inform schoolwide intervention efforts such as multilevel, positive behavior support (PBS) programs. In a recent study by Lane, Wehby, Robertson, and BartonArwood (2005), three high schools that were parricipating in a federally-funded grant to study PBS at the secondary level participated in a yearlong training program to design site-specific PBS plans. As part of the training process, PBS teams

\section{[T] he consequences of not meeting teachers' expectations may result in a variety of pejorative outcomes within and beyond the school setting.}

from each school surveyed each of their faculties to identify specific skills that their teachers viewed as essential for school success. One school used this information to develop a comprehensive program that involved schoolwide instruction in "student success skills" that entailed explicitly teaching one skill a month to the entire student body. The goal of the program was to (a) ensure that all students were aware of teacher expectations, (b) promote continuity of teacher expectations across classrooms, and (c) reinforce students who exhibited the desired behaviors. Other schools used the information to refine or redefine schoolwide rules and expectations.

Second, information on teacher expectations can also be used to improve interventions designed by prereferral intervention teams (Lane, Givner, \& Pierson, 2004). If the goals of the interventions generated by the prereferral intervention teams are aligned with teacher expectations, the skills acquired via the intervention are more likely to be reinforced beyond the training condition (Sulzer-Azaroff \& Mayer, 1991). This will increase the likelihood of the newly acquired skills generalizing and maintaining, a goal of all intervention efforts (Baer, Wolf, \& Risley, 1987).

Third, information on teacher expectations may also prove useful in facilitating transitions across the grade span, particularly as students transition from elementary to middle school and from middle to high school (Isakson \& Jarvis, 1999). 
During the initial transition from elementary school to middle school, students must shift from meeting the expectations of one teacher to negotiating the expectations of several teachers over the instructional day (Seidman et al., 1994). If teachers both within and between grade levels differ in their expectations of student performance, elementary students should be made aware of these differences prior to beginning the transition to middle school. This would allow students to identify how they must adjust academically, socially, and behaviorally to successfully navigate the expectations of multiple teachers. Similarly, the transition between middle to high school is defined by increased teacher demands as students are required to master increasingly differentiated curricula (Isakson \& Jarvis). Understanding differences and similarities among teacher expectations across the grade span and providing this information to students may enable them to better negotiate student-teacher relationships in subsequent grade levels (O'Shaughnessy, Lane, Gresham, \& BeebeFrankenberger, 2002).

Fourth, understanding how general and special education teachers converge and diverge in their expectations for student decorum may also improve educational experiences for students educated in inclusive environments (Lane, Pierson, \& Givner, 2004). For example, if students with exceptionalities could be made aware of differences in special and general education teachers' expectations and then are explicitly taught the skills viewed as critical to success, these youngsters may experience improved inclusive experiences. With the call for inclusive programs in conjunction with the call for high levels of student achievement for all learners (Fournier, 2002; No Child Left Behind Act, 2001), it is imperative that every effort be made to proactively manage student behavior with the goal of promoting effective, effcient instruction.

Earlier investigations of teachers' expectations of classroom behavior conducted in the 1980s suggested that general and special education teachers at the elementary and secondary levels (Kerr \& Zigmond, 1986; Walker \& Rankin, 1983) generally shared similar views regarding the importance of compliance, self-control, and study habits (Kerr \& Zigmond). However, general education teachers, as compared to special education teachers, placed greater emphasis on standards for classroom behavior. Investigations by Gresham, Lane, and colleagues extended this line of inquiry by examining the extent to which other teacher characteristics such as gender, teaching experience, and grade level taught were predictive of teacher expectations (Gresham et al., 2000; Lane, Givner et al., 2004; Lane, Pierson et al., 2004). Results indicated that elementary, middle, and high school teachers placed significantly less emphasis on assertion skills as compared to cooperation and self-control skills. Further, grade level taught and program taught (general or special education) was predictive of the value placed on assertion skills. Specifically, teachers who worked with younger students and general education teachers rated assertion skills as more critical for school success as compared to teachers who worked with older students and special education teachers. As was the case with Kerr and Zigmond's (1986) study, general education elementary teachers placed greater emphasis on cooperation skills than did special education teachers (Lane, Pierson et al., 2004).

In a similar line of inquiry, Walker, Irvin, Noell, and Singer (1992) developed the model of interpersonal social-behavioral competence within school settings that illustrates elementary teachers' preferred and nonpreferred behaviors. This model delineates adaptive student out omes (e.g., friendships, academic success) associated with demonstrating teacher- and peer-preferred behaviors as well as maladaptive student outcomes (e.g., impaired social relationships, school failure) associated with demonstrating behaviors not preferred by teachers and students.

Although there appears to be consistency across a number of studies in this area, a significant limitation in this body of work is the lack of a systematic examination of the extent to which teacher expectations vary as a function of the level of risk associated with a school's student population. Teacher expectations at high-performing and low-risk schools may differ from teacher expectations at low-performing and high-risk schools. For example, teachers working in schools with high rates of poverty, student absenteeism, disruptive behavior, student mobility, as well as low achievement scores may focus their attention on expectations related to minimizing disruptions to 
instruction (e.g., managing inappropriate behavior, coming to class on time). Consequently, it may be that teachers in more at-risk environments emphasize the importance of self-control or cooperation skills and deemphasize the importance of assertion skills in an effort to maintain harmony, avoid conflict, and focus on instructional activities. Or it may be just the opposite. Perhaps teachers in more at-risk environments may expect and reinforce higher levels of assertiveness in an effort to help students access educational experiences that may not be typically available in low-performing and high-risk schools with the goal of encouraging students to obtain a strong education.

In contrast, teachers working in high-performing, affluent schools with low rates of student absenteeism and high rates of achievement may articulate expectations related to maximizing instructional opportunities (e.g., working cooperatively on assignments, participating in extracurricular activities). Perhaps these more affluent schools have the resources to provide students with a more comprehensive educational experience. Students in these environments may not have to learn assertion skills to obtain these experiences. Also, it is possible that self-control skills may not be viewed as critical by these teachers as these students may face fewer potential incidences of conflict within and beyond the school setting.

There is some evidence that socioeconomic status (SES) may influence teacher ratings of child characteristics. Alvidrez and Weinstein (1999) reported that after controlling for IQ, teachers overestimated the academic skills of children who were living in higher socioeconomic situations and underestimated the ability of students who resided in lower socioeconomic situations. Similarly, in a study of inclusive teachers' attitudes toward students with disabilities, Cook (2004) reported that teachers in high SES school districts were more likely to identify children with disabilities as needing more attention than teachers in lower SES school systems. Likewise, teachers in high SES districts were more likely to reject included students with disabilities than teachers in low SES districts. As reported by Alvidrez and Weinstein, these findings are consistent with previous reviews of the relationship between SES and teacher attitudes (Baron, Tom, \& Cooper, 1985; Dusek \& Joseph, 1983).

In light of the recent emphasis on unified evaluations regarding academic achievement across all types of schools and the relation between student behavior and academic achievement, it is necessary to determine the degree to which schools of differing risk status are consistent in their expectations of student behavior. This study addresses this limitation.

Given the importance of understanding teachers' expectations across program areas and grade levels, as well as the lack of information regarding the consistency of teacher expectations in schools of varying risk status, this study has two primary objectives. The first objective is to replicate the findings of recent investigations into teacher expectations by examining (a) the relationship of grade level (elementary vs. middle vs. high school) and type of program (general vs. spe-

\section{... it is necessary to determine the degree to which schools of differing risk status are consistent in their expectations of student behavior.}

cial education) to teachers' perceptions of the necessity of self-control, cooperation, and assertion skills; and (b) the specific skills rated by the majority of the general and special education respondents as critical or not important for school success. The second objective of this study is to extend this line of inquiry by determining if teachers' ratings of self-control, cooperation, and assertion skills were similar across schools with high- and low-risk status.

\section{METHOD}

\section{PARTICIPANTS}

A total of 717 teachers at seven elementary $(n=$ $210 ; 29.29 \%)$, eight middle ( $n=259 ; 36.12 \%)$, and four high $(n=248 ; 34.59 \%)$ schools in a large, socioeconomically and culturally diverse district in middle Tennessee completed a brief, 


\begin{tabular}{|c|c|c|c|c|c|c|c|c|}
\hline \multirow[b]{2}{*}{ Variable } & \multicolumn{2}{|c|}{$\begin{array}{c}\text { Elementary } \\
\mathrm{n}=210\end{array}$} & \multicolumn{2}{|c|}{$\begin{array}{l}\text { Middle } \\
\mathrm{n}=259\end{array}$} & \multicolumn{2}{|c|}{$\begin{array}{c}\text { High } \\
\mathrm{n}=248\end{array}$} & \multicolumn{2}{|c|}{$\begin{array}{c}\text { Total Sample } \\
\mathrm{n}=717\end{array}$} \\
\hline & Percentage & $\mathbf{n}$ & Percentage & $n$ & Percentage & $\mathrm{n}$ & Percentage & $\mathbf{n}$ \\
\hline \multicolumn{9}{|l|}{ Gender } \\
\hline Male & 8.78 & 18 & 23.48 & 54 & 31.94 & 69 & 21.66 & 141 \\
\hline Female & 91.22 & 187 & 76.52 & 175 & 68.06 & 147 & 78.34 & 509 \\
\hline \multicolumn{9}{|l|}{ Program Type } \\
\hline General & 69.95 & 140 & 68.53 & 159 & 69.86 & 153 & 69.33 & 452 \\
\hline Special & 9.95 & 20 & 16.81 & 39 & 15.53 & 34 & 14.26 & 93 \\
\hline Other & 20.40 & 41 & 14.66 & 34 & 14.61 & 32 & 16.41 & 107 \\
\hline \multicolumn{9}{|l|}{ Credential Status } \\
\hline Certificated & 96.12 & 198 & 92.67 & 215 & 94.31 & 199 & 94.30 & 612 \\
\hline Substitute/Emergency & 3.88 & 8 & 7.33 & 17 & 5.69 & 12 & 5.70 & 37 \\
\hline \multicolumn{9}{|l|}{ Teaching Experience } \\
\hline Novice & 20.00 & 42 & 40.93 & 106 & 41.13 & 102 & 33.96 & 250 \\
\hline Experienced & 80.00 & 168 & 59.07 & 153 & 58.87 & 146 & 63.45 & 467 \\
\hline \multicolumn{9}{|l|}{ Educational Level } \\
\hline Bachelor's Degree & 48.29 & 99 & 42.55 & 100 & 33.03 & 72 & 41.19 & 271 \\
\hline Master's Degree & 30.73 & 63 & 36.17 & 85 & 36.24 & 79 & 34.50 & 227 \\
\hline Master's + 30 Units & 19.51 & 40 & 17.87 & 42 & 25.69 & 56 & 20.97 & 138 \\
\hline Educational Specialist & 0.98 & 2 & 0.85 & 2 & 1.83 & 4 & 1.22 & 8 \\
\hline Doctorate & 0.49 & 1 & 1.70 & 4 & 2.75 & 6 & 1.67 & 11 \\
\hline Other & 0.00 & 0 & 0.85 & 2 & 0.46 & 1 & 0.46 & 3 \\
\hline
\end{tabular}

Note. Percentage is computed based on the number of participants who completed a given item.

anonymous questionnaire, a modified version of the teacher expectation survey developed by Lane, Givner et al. (2004) to examine teacher expectations of student behavior in general and special education classrooms. Of the 717 respondents who provided gender information, $141(21.66 \%)$ were male and $509(78.34 \%)$ were female (see Table 1).

Chi-square analyses contrasting school level $\mathrm{X}$ program, school level $\mathrm{X}$ credential status, program $X$ gender, program $X$ teaching experience, credential status $X$ gender, and gender $X$ teaching experience did not reveal significant differences. Chi square analyses contrasting school level $\mathrm{X}$ gender $\left[\chi^{2}(2, N=651)=33.95, p<0.0001\right.$, phi coefficient $=0.22]$, school level $\mathrm{X}$ teaching experience $\left[\chi^{2}(2, N=717)=28.91, p<0.0001\right.$, phi coefficient $=0.20]$, and credential status $\mathrm{X}$ teaching experience $\left[\chi^{2}(1, N=649)=52.74, p<\right.$
0.0001 , phi coefficient $=0.29]$ did reveal significant differences. The differences among groups with respect to gender are reflective of national differences (National Education Associarion [NEA], 2004.). The NEA indicates that the number of male elementary teachers has declined from $18 \%$ in 1981 to $9 \%$ today. Whereas men constituted $50 \%$ of the teachers in the mid-1980s, they now constitute $35 \%$ of secondary teachers. Because of low cell sizes, chi-square analyses of degree atrainment with other demographic variables were not possible, nor was a comparison of program X credential status.

\section{PROCEDURES}

As previously mentioned, this study was conducted in a large, socioeconomically and culturally diverse district in middle Tennessee. As of the 2001-2002 school year, this district served 68,277 
students and was among the top 50 largest school districts in the United States (Tennessee Department of Education, 2003). The district is highly diverse with $56.3 \%$ of the student population from traditionally underrepresented groups (46.7\% Black, 6.1\% Hispanic, 3.3\% Asian, and $.2 \%$ Native American). The district serves students at a variety of socioeconomic levels with $56.7 \%$ of the students receiving free/reduced meals. In addition, $31 \%$ of the population is enrolled in Title I programs. Further, the district hosts a number of students who require special education services. In the 2001-2002 school year, $15.5 \%$ of all students were identified as having individualized education programs. Finally, during the same period, the dropout rate among 9th through 12 th graders was estimated at $13 \%$.

These demographics for this district are compatible with national averages for other large school districts in the United States. For example, according to the U.S. Department of Education, National Center for Education Statistics (2002), $54 \%$ of students in the 100 largest school districts in the country are eligible for free/reduced meals; whereas $12 \%$ of students in these same districts have some type of individualized education program. In addition, the percentage of minority enrollment in these large districts is $68 \%$.

Initially, a total of 43 schools in this district with one or more self-contained classes for students with exceptionalities were invited to participate in this investigation. Twenty-nine (66\%) principals agreed to participate by allowing project staff to survey the school site teachers to obtain information on their expectations of student behavior. Information on the teachers' expectations was obtained in one of two ways. The first method, our proposed method of data collection, involved having project staff attend a regularly scheduled faculty meeting where we overviewed the purpose of the project, distributed an explanatory letter, obtained teacher consent, and collected the completed questionnaires before the end of the meeting. Fifteen schools $(51.72 \%)$ participated in this method of data collection. In the second method, the explanatory letter, teacher consent forms, and the questionnaires were dropped off in individual teacher mailboxes. If teachers agreed to participate, they dropped off completed questionnaires in a slotted, sealed card- board box in the school office within a week of their distribution. The remaining 14 schools (48.28\%) participated in this method of data collection. Chi-square analyses contrasting method of data collection $\mathrm{X}$ school risk (low and high, definition to follow) $\left[\chi^{2}(1, N=29)=1.01, p=\right.$ 0.3756 ] did not reveal a significant difference.

Average response rates of participating teachers varied depending on the method of data collection with a mean response rate of $78.27 \%$ $(S D=19.09$; range $=25 \%$ to $97.62 \%)$ for sitevisit schools and $42.51 \%(S D=28.53 \%$; range $=$ $5.26 \%$ to $93.33 \%$ ) for drop-off schools. Schools with responses from $50 \%$ or more of the teachers were included in the analysis to increase the probability of including a representative sample of each school. As a result, data from 19 schools (14 using the site-visit data-collection procedures and 5 using the drop-off format) were used in the data analysis $(M=79.63 \% ; S D=14.75$; range $=$ $51.79 \%$ to $97.62 \%$ ).

Once completed questionnaires were collected, unique identification numbers were assigned to individual teachers, and data were entered by the project staff. Ten percent of the questionnaires were randomly selected to verify the accuracy of data entry. Any detected errors (less than 1\%) were corrected.

\section{INSTRUMENT}

A modified version of the Teacher Expectations for School Success questionnaire (see Lane, Givner et al., 2004) was used in this investigation. The questionnaire contained two sections: social skills items and teacher demographic information. The social skills section contained 30 social skills items from the Social Skills Rating System (SSRS; Gresham \& Elliott, 1990). The 30 items are equally distributed across three factor analytically derived domains: cooperation (e.g., uses time appropriately while waiting for help), assertion (e.g., joins ongoing activity or group without being told to do so), and self-control (e.g., controls temper in conflict situation with peers). The SSRS has strong psychometric properties with coefficient alpha reliabilities ranging from 0.85 to 0.94 across the three social skills domains. The total scale coefficient alpha was 0.94 for males and 0.93 for females (Gresham \& Elliott). Coefficient 
alphas for the three scales based on the participants in this study were as follows: cooperation, .81 and .73; assertion, .77 and .84; and self-control, .78 and .79 for elementary and secondary versions, respectively

Teachers rated the importance of each skill as it related to student success in their classrooms on a 3-point Likert-type scale (not important $=0$, important $=1$, critical $=2$ ). Composite scores for each domain were computed by adding the ratings for the 10 items constituting each domain (range: 0 to 20). The importance items of the elementary and secondary versions were factor analyzed separately using the principal axis method to extract factors, followed by a promax (oblique) rotation. Squared multiple correlations served as prior communality estimates. Results of the scree tests revealed three factors on borh the elementary and secondary versions that were retained for rotation. On the elementary version, factor loadings ranged from .53 to .100 on the cooperation factor, .52 to .100 on the assertion factor, and .31 to .100 on the self-control factor. Interfactor correlations ranged from .28 to .43 . On the secondary versions factor loadings ranged from .34 to .60 on the cooperation factor, .40 to .73 on the assertion factor, and .39 to .64 on the self-control factor. Interfactor correlations ranged from .23 to .45 .

Next, teachers completed the demographic information section. Teachers identified their gender, current grade level taught; program area, teaching experience, teaching credentials, and highest degree attained. Categorical variables were created as follows: (a) current grade level taught was grouped into elementary (kindergarten through Grade 4), middle (Grade 5 through Grade 8), and high school (Grade 9 through Grade 12) levels in accordance with middle Tennessee's grouping practices; (b) program area referred to general or special education; (c) teaching experience was divided into novice (less than 5 years) and experienced ( 5 or more years) in accordance with previous investigations (Lane, Givner et al., 2004); (d) teaching credentials were coded as credentialed (teachers held clear certifications) and noncredentialed (teachers with emergency credentials or waivers); and (e) highest degree held was divided into bachelor's of arts or science, master's degree, master's degree plus 30 units, Ed.S, or doctorate. Additional information was not requested to promote higher return rates and ensure teacher anonymity.

\section{RES U L T S}

Objective 1: To examine the relationship of grade level (elementary vs. middle vs. high school) and type of program (general vs. special education) to teachers' perceptions of the importance of self-control, cooperation, and assertion skills in their students.

\section{STATISTICAL ANALYSES}

Three 2-way fixed-effects analyses of variance (ANOVAs) were computed using the general linear model to compare differences between program type (general vs. special education) and school leved (elementary vs. middle vs. high school) with respect to teachers' expectations of students' social competence in the areas of self $f_{\bar{i}}$ control, cooperation, and assertion skills. Both school level and program type were treated as fixed-effects factors. Composite scores for assets tion, sself-control, and cooperation domain served as dependent variables. The Bonferronit correction (0.05/3) was used to correct for Type I errors given that three separate ANOVAs were conducted.

ANOVAs yielding significant differences between group means were followed by the Tukey-Kramer modification of the honestly significant difference (HSD) simultaneous confidence interval technique to determine mean differences $(\alpha=.05)$. This technique substitutes the harmonic mean $(M=273, S D=254.56)$ to contrast for unequal group sizes. A multivariate analysis of variance (MANOVA) was not conducted given that two of the variables (assertion and cooperation) were highly correlated $(r=0.63$; Kleinbaum, Kupper, Muller, \& Nizam, 1998). Effect sizes were computed using the pooled standard deviation in the denominator for all significant effects (Lipsey \& Wilson, 2001). Effect sizes can be interpreted as follows: 0 to 0.3 is a small effect, 0.3 to 0.8 is a moderate effect, and 0.8 or above is a large effect (Cohen, 1988). See Table 2 for group means and standard deviations on cooperation, assertion, and self-control composite scores. 


\begin{tabular}{lcccc}
\hline & & \multicolumn{3}{c}{ Skill Area } \\
\cline { 3 - 5 } Grade Level & Program Type & $\begin{array}{c}\text { Self-Control } \\
\mathrm{M}(\mathrm{SD})\end{array}$ & $\begin{array}{c}\text { Cooperation } \\
\mathrm{M}(\mathrm{SD})\end{array}$ & $\begin{array}{c}\text { Assertion } \\
\mathrm{M}(\mathrm{SD})\end{array}$ \\
\hline Elementary & & $15.04(2.90)$ & $14.46(3.18)$ & $9.69(2.97)$ \\
& General Education & $15.03(2.99)$ & $14.67(3.15)$ & $9.63(3.02)$ \\
& Special Education & $15.15(2.21)$ & $13.00(3.04)$ & $10.15(2.60)$ \\
\multirow{3}{*}{ Middle } & & $13.98(3.12)$ & $14.30(2.73)$ & $8.90(3.66)$ \\
& & $13.96(3.02)$ & $14.45(2.61)$ & $8.94(3.65)$ \\
& General Education & $14.08(3.53)$ & $13.69(3.15)$ & $8.74(3.73)$ \\
High School & Special Education & $13.11(3.28)$ & $14.41(2.92)$ & $8.26(3.77)$ \\
& & $12.69(3.12)$ & $14.71(2.68)$ & $8.08(3.65)$ \\
& General Education & $15.03(3.35)$ & $13.03(3.53)$ & $9.03(4.21)$ \\
\hline
\end{tabular}

\section{FINDINGS}

Self-Control. Results of two-way ANOVAs with two between-groups factors (school level and program type) with self-control as the outcome variable produced a significant school level taught $\mathrm{X}$ program type interaction, $F(2,539)=4.62$, $p=.0102$. A simple effect for program type for elementary teachers was not significant nor was a simple effect for program type for middle school teachers. These findings indicated that general and special education teachers at the elementary and middle school levels shared similar views regarding the importance of self-control skills. A final simple effect for program type for high school teachers was significant, $F(1,185)=$ $15.24, p=.0001$, effect size $(d)=.72$, with high school special education teachers viewing selfcontrol as significantly more important for school success as compared to high school general education teachers.

Cooperation. Results of the two-way ANOVA with two between-groups factors (school level taught and program type) revealed that the school level X program type interaction was not significant. The main effect of school level was not significant indicating that elementary, middle, and high school teachers had similar views on the importance of cooperation skills. The main effect of program type was significant, $F(1,539)=$ $15.68, p<.0001$, effect size $(d)=.43$, indicating that special education teachers viewed cooperation skills as significantly less important for success relative to general education teachers.

Assertion. Results of the two-way ANOVA with two between-groups factors (school level taught and program type) revealed that the school level X program type interaction was not significant. The main effect of school level was significant, $F(2,539)=7.42, p=0.0007$, with high school teachers rating assertion skills as significantly less important $(M=8.26 ; S D=3.77)$ than did elementary $[M=9.69 ; S D=2.97$, effect size $(d)=.0 .44]$ or middle $[M=8.90 ; S D=3.66$, effect size $(d)=.17]$ school teachers. The main effect of program type was not significant indicating that special and general education teachers rated assertion skills as equally important for school success.

Objective 2: To examine the specific skills rated by the majority of the general and special education respondents as critical or not important for school success.

\section{STATISTICAL ANALYSES}

Frequency tables were examined to identify the social skills that the majority of teachers $(>50 \%)$ 


\begin{tabular}{|c|c|c|c|c|}
\hline Items & Domain & $\begin{array}{c}\text { Elementary } \\
\mathrm{n}=210 \\
\%(\mathrm{n})\end{array}$ & $\begin{array}{c}\text { Middle } \\
\mathrm{n}=259 \\
\%(\mathrm{n})\end{array}$ & $\begin{array}{c}\text { High } \\
\mathrm{n}=248 \\
\%(\mathrm{n})\end{array}$ \\
\hline
\end{tabular}

E1, S18: Controls temper in conflict situation with peers

\begin{tabular}{llll} 
Self-Control & $83.33(175)$ & $81.78(211)$ & $75.20(185)$ \\
Self-Control & $50.48(105)$ & $50.39(130)$ & \\
Cooperation & $52.63(110)$ & & \\
Self-Control & $87.62(184)$ & $80.47(206)$ & $72.36(178)$ \\
\hline Cooperation & $89.90(187)$ & $76.65(197)$ & $79.27(195)$ \\
Self-Control & $69.86(146)$ & $60.08(155)$ & \\
& & & \\
Cooperation & $52.17(108)$ & $53.52(137)$ & \\
Cooperation & $74.64(156)$ & $78.38(203)$ & $81.30(200)$ \\
& & & \\
Cooperation & $50.72(106)$ & $55.64(143)$ & $52.24(128)$ \\
Cooperation & $66.99(140)$ & &
\end{tabular}

E5, S30: Responds appropriately to peer pressure

E8: Uses free time in an acceptable way

E12, S23: Controls temper in conflict situations with adults

E20: Follows your directions;

S29: Complies with your directions

E25: Responds when pushed or hit;

S3: Responds to physical aggression

E26, S24: Ignores peer distractions when doing classwork

E28, S12: Attends to your instructions

E29, S17: Easily makes transitions from one classroom activity to another

E30: Gets along with people who are different

S1: Produces correct schoolwork

Cooperation

$53.25(131)$

S8: Responds appropriately to teasing by peers

S11: Receives criticism well

Self-Control

Self-Control

S13: Uses time appropriately while waiting

for your help

Cooperation

$54.83(142)$

S20: Listens to classmates when they present

their work or ideas

Cooperation

$54.65(141)$

$57.72(142)$

Note. Percentages are only reported for those cells with values greater than $50 \%$. E refers to items from the elementary version of the Social Skills Rating System (Gresham \& Elliott, 1990), and S refers to items from the secondary version.

rated as critical (see Table 3) or not important (see Table 4) for school success. Critical was defined as an importance score of 2 (critical) and not important was defined as an importance score of zero (not important).

\section{FINDINGS}

Skills Critical for Success. The majority of elementary and middle school teachers identified 10 skills as critical for school success (see Table 3). Specifically, the majority of elementary and middle school teachers rated four items related to self- control and six items related to cooperation as critical. In contrast, seven items (two self-control, five cooperation) were rated as critical for school success by the majority of high school teachers. Five of the items, controls temper in conflict situation with peers, controls temper in conflict situation with adults, follows/complies with directions, attends to your instructions, and easily makes transitions from one classroom activity to another were consistent across the three grade levels. None of the assertion items were rated as critical by the majority of the teachers. 


\begin{tabular}{ccccc}
\hline & & Elementary & Middle & High \\
& & $\mathrm{n}=210$ & $\mathrm{n}=259$ & $\mathrm{n}=248$ \\
Items & Domain & $\%(\mathrm{n})$ & $\%(\mathrm{n})$ & $\%(\mathrm{n})$ \\
\hline
\end{tabular}

E2: Introduces self to new people without being told

Assertion $\quad 54.84(119)$

S28: Gives compliment to members of the opposite sex

Assertion

$58.62(153)$

$62.35(154)$

Note. Percentages are only reported for those cells with values greater than $50 \%$. E refers to items from the elementary version of the Social Skills Rating System (Gresham \& Elliotr, 1990), and S refers to items from the secondary version.

Skills Not Important for Success. The majority of elementary school teachers rated only one item, introduces self to new people without being told, as not important for success $(54.84 \%)$. The majority of middle and high school teachers also rated one item, gives compliments to members of the opposite sex, as not important for school success (see Table 4). None of the self-control and cooperation skills were rated as not important by the majority of elementary, middle, or high school teachers (see Table 3). Table 5 shows the mean scores by comparison groups.

Objective 3: To determine if teachers' ratings of selfcontrol, cooperation, and assertion skills were similar across schools with high-and low-risk status.

\section{STATISTICAL ANALYSES}

Three independent-samples $t$ tests were conducted to identify differences in teachers' ratings of self-control, cooperation, and assertion skills between schools with high- and low-risk status. Effect sizes (Busk \& Serlin, 1992) were computed as previously described to evaluate the magnitude of significant differences. Risk status was determined based on the percentage of students receiving free or reduced lunches. This variable was intended to serve as proxy for SES given that poverty itself is associated with negative school and life outcomes (Costello, Keeler, \& Angold, 2001; Eamon, 2001; Yates, Egeland, \& Sroufe, 2003). Specifically, schools that exceeded the district mean $(M=56.7)$, which is representative of the national mean, were coded as high risk, and those who did not meet this criteria were coded as low risk.

\section{FINDINGS}

Results revealed a significant difference between at-risk and non at-risk schools on self-control, $t(715)=-2.85, p=0.0045$ and assertion variables $t(715)=-2.06, p=0.0395$, with teachers at highrisk schools rating self-control $[M=14.53, S D=$ 3.06; effect size $(d)=0.22]$ and assertion $[M=$ $9.51, S D=3.45$, effect size $(d)=0.16]$ skills as more critical for school success as compared to teachers at low-risk schools $(M=13.84, S D=$ 3.26 and $M=8.95, S D=3.68$, respectively). Although significant, effect size values indicate a low effect between at-risk and non at-risk schools for both self-control and assertion variables. There were no significant differences between high-risk $(M=14.47, S D=3.05)$ and low-risk $(M=14.42$, $S D=2.96$ ) schools in terms of cooperation skills. This suggests that teachers at both types of schools rated cooperation skills as equally important for school success.

\section{DISCUSSION}

Students who fail to navigate successfully teachers' expectations may be at risk for a range of deleterious outcomes both within and beyond the school setting (e.g., academic underachievement and impaired social relationships). Obtaining a better understanding of differences and similarities in teacher expectations across the grade span and across different types of teachers (e.g., general 


\begin{tabular}{|c|c|c|c|}
\hline \multirow[b]{2}{*}{ Group Compared } & \multicolumn{3}{|c|}{ Skill Area } \\
\hline & $\begin{array}{l}\text { Self-Control } \\
\text { M (SD) }\end{array}$ & $\begin{array}{c}\text { Cooperation } \\
\mathrm{M}(\mathrm{SD})\end{array}$ & $\begin{array}{l}\text { Assertion } \\
\text { M (SD) }\end{array}$ \\
\hline Total Sample & $14.12(3.20)$ & $14.44(3.00)$ & $9.17(3.60)$ \\
\hline \multicolumn{4}{|l|}{ Gender } \\
\hline Male & $13.30(3.32)$ & $13.75(3.19)$ & $8.45(4.06)$ \\
\hline Female & $14.35(3.13)$ & $14.57(2.92)$ & $9.31(3.49)$ \\
\hline \multicolumn{4}{|l|}{ Grade Level Taught } \\
\hline Elementary (K-5) & $15.16(2.94)$ & $14.51(3.12)$ & $9.96(3.06)$ \\
\hline Middle School (6-8) & $14.07(3.11)$ & $14.36(2.82)$ & $8.99(3.63)$ \\
\hline High School (9-12) & $13.29(3.25)$ & $14.46(3.07)$ & $8.70(3.88)$ \\
\hline \multicolumn{4}{|l|}{ Program Type } \\
\hline General & $13.86(3.18)$ & $14.61(2.81)$ & $8.87(3.52)$ \\
\hline Special & $14.66(3.23)$ & $13.30(3.25)$ & $9.15(3.71)$ \\
\hline Other & $14.48(3.15)$ & $14.47(3.27)$ & $10.07(3.90)$ \\
\hline \multicolumn{4}{|l|}{ Credential Status } \\
\hline Certificated & $14.13(3.21)$ & $14.46(2.95)$ & $9.08(3.61)$ \\
\hline Substitute/Emergency & $14.03(2.72)$ & $14.08(2.82)$ & $9.57(3.52)$ \\
\hline \multicolumn{4}{|l|}{ Experience } \\
\hline Novice (< 5 years) & $13.95(3.04)$ & $14.44(2.99)$ & $9.31(3.33)$ \\
\hline Experienced $(5+$ years $)$ & $14.21(3.28)$ & $14.44(2.99)$ & $9.10(3.74)$ \\
\hline \multicolumn{4}{|l|}{ Educational Level } \\
\hline Bachelor's Degree & $14.15(3.23)$ & $14.52(2.92)$ & $9.38(3.63)$ \\
\hline Master's Degree & $13.82(3.19)$ & $14.31(2.93)$ & $8.58(3.60)$ \\
\hline Master's + 30 Units & $14.45(3.22)$ & $14.43(3.01)$ & $9.36(3.80)$ \\
\hline Educational Specialist & $14.50(1.60)$ & $13.00(3.63)$ & $9.88(1.46)$ \\
\hline Doctorate & $14.64(3.29)$ & $15.09(2.98)$ & $9.91(2.66)$ \\
\hline Other & $13.00(2.65)$ & $11.33(3.06)$ & $9.33(3.51)$ \\
\hline
\end{tabular}

versus special education teachers) has the potential to improve students' educational experiences (Lane, Givner et al., 2004; Walker et al., 1992). The present study extended this line of inquiry by exploring (a) the effects of grade level (elementary vs. middle vs. high school) and type of program (general vs. special education) on teachers' perceptions of the importance of self-control, cooperation, and assertion skills; (b) the specific skills rated by the majority of the general and special education respondents as critical or not important for school success; and (c) the degree to which teacher characteristics predicted value teachers placed on self-control, cooperation, and assertion skills. This study also extended earlier investigations by examining potential differences in teachers' perception of self-control, cooperation, and assertion skills across schools with high- and lowrisk status.

Results indicated that general and special education teachers at the elementary and middle school levels shared similar views regarding the importance of self-control skills, whereas high school special education teachers viewed self-control skills as significantly more important than did high school general education teachers. Although 
elementary, middle, and high school teachers had similar views on the importance of cooperation skills, special education teachers rated cooperation skills as significantly less important for success relative to general education teachers. In terms of assertion, high school teachers rated assertion skills as significantly less important as compared to elementary or middle school teachers. Special and general education teachers rated assertion skills as equally important for school success.

These findings closely parallel earlier investigations (Kerr \& Zigmond, 1986; Lane, Pierson, \& Givner, 2004) suggesting that teacher expectations are highly consistent, with teachers emphasizing skills that facilitate rather than impede instruction. This is particularly evident with the tremendous emphasis teachers placed on self-control and cooperation skills. Moreover, none of the assertion items were rated as critical for success, whereas all items rated as not important for success came from the assertion domain. Furthermore, of the five skills rated as critical for success by the majority of elementary, middle, and high school teachers, four skills were also rated as critical for success in a previous study (Lane, Pierson et al., 2003), and three skills were also identified as critical by Kerr and Zigmond and Walker and colleagues (1992). These outcomes are highly consistent with previous investigations, which suggested that teachers place greater value on cooperation and self-control skills as compared to assertion skills and that there are subtle differences in teacher expectations across the grade span as well as between general and special education teachers.

Finally, results also indicated that there are differences in teacher expectations between teachers working at high- and low-risk schools. Although there were no differences in the value teachers placed on cooperation skills, teachers at high-risk schools viewed self-control and assertion skills as more critical for school success as compared to teachers at low-risk schools. Teachers at high-risk schools may view assertion skills as more necessary to meet their education needs given the tendency for students to (a) enter and leave school at an increased rate and (b) participate in fewer enrichment experiences relative to students at low-risk schools. The former students may need to be more assertive in seeking assistance and other educational opportunities to avoid having instructional gaps and further their learning experiences. Similarly, teachers at high-risk schools may view self-control as more necessary for a number of reasons. First, students in highrisk schools may be more likely to encounter situations in which antisocial behavior (e.g., fighting, arguing) is a likely outcome. Under these conditions, teachers in high-risk schools may value a student's ability to manage his or her own behavior in order to prevent interactions with peers or adults from escalating to unacceptable levels.

\section{...teacher expectations are highly consistent, with teachers emphasizing skills that facilitate rather than impede instruction.}

Also, teachers in high-risk schools may have fewer resources (e.g. parent volunteers, extra staff) to effectively supervise and support students throughout the school day. If so, these same teachers might encourage students to take some responsibility in the management of their daily activities and to place a high value on self-reliance both in academic and social situations.

\section{LIMITATIONS AND FUTURE DIRECTIONS}

As with all studies, there are specific limitations that warrant attention. As with previous teacher expectation studies, all information is obtained through the use of teacher-reported data. Future investigations could be enhanced by using more direct techniques (e.g., direct observation data) to determine if the skills rated as critical by teachers are the same skills that are reinforced in the school setting. For example, teachers may rate skills such as follows instructions as essential for success when in actuality they actually provide more reinforcement (in the form of teacher attention) to students who are not following instructions. Second, this study is predicated on the notion that teachers hold similar expectations for all students. However, it may be that teachers differentiate their expectations based on individual 
student characteristics (Gresham et al., 2000). For example, teachers may hold different expectations for students with behavioral problems, limited cognitive ability, or limited skill sets. Finally, although this study takes an important next step by examining expectations across different school types (e.g., low risk and high risk), this work is limited in the sense that "risk" was defined using only one variable-percentage of free and reduced lunch-which was intended to serve as a proxy for socioeconomic status. Future studies could be enhanced by elaborating on the definition of risk to also include variables such as academic performance, attendance rates, mobility rates, and/or percentage of special education enrollment. Finally, although response rates were relatively strong, we did not have total participation. Because we have no method of determining if responders and nonresponders differ in their expectations, we must interpret the findings from this study with caution. Despite these limitations, this study both confirms and extends the teacher expectation knowledge base.

\section{IMPLICATIONS FOR PRACTICE AND FUTURE RESEARCH}

The findings have a variety of implications for practice. First, it is important to note that in most areas, there was consistency in the ratings from general educators and special educators. For example, at the elementary and middle school levels, self-control was rated as an important skill, regardless of the type of education a student was receiving. Given the perceived importance of selfcontrol, it seems essential that this skill be included in the teaching of school expectations at these levels. Instructing students on self-control strategies might be incorporated in a schoolwide positive behavior support plan or be directly taught with classroom-based social skill curricula. In addition, awareness of the importance of selfcontrol should be emphasized when special education students are being considered for inclusion into general education classrooms.

Similarly, given the importance placed on cooperation by general education teachers, special education programs should incorporate assessment and direct teaching of cooperation in order to facilitate placement into less restrictive class- room settings. The direct teaching of self-control and cooperation should include systematic analysis of the dimensions of these skills in general education classrooms. This assessment might include observations in general education classrooms to determine both topographies of selfcontrol and cooperation that are needed as well as identification of the types of general education activities that are most likely to require these behaviors. This information could then be used to determine the types of lessons that are required for teaching these two valued skills.

Finally, given the differences between high school teachers as compared with elementary and middle educators, it appears that borh general education and special education students need preparation in those skills that are more valued at the secondary level. From these data, it appears that the focus of this preparation should emphasize assertiveness training. Again, a more specific understanding of the types of assertive skills needed as well as an identification of the situations in which these skills are most likely to be used would aid both general education and special education teachers in the development of training activities. Overall, this study emphasizes the need for monitoring cooperation, assertiveness, and self-control skills of all students as they progress through the kindergarten through 12 thgrade system.

In sum, teacher expectations appear to be consistent across the grade span and program types with subtle, but important, differences. Further, teacher expectations vary as a function of the level of school risk. Collectively, these findings, in conjunction with previous literature in this area, provide insight and direction for this line of inquiry. Additional research is needed to identify ways in which schools and parents can use this information to better prepare students to successfully meet these expectations. If used properly, this research may improve the educational experiences (e.g., transitions across the grade span and inclusive experiences for students with and without exceptionalities) of all students. Future investigations may be wise to examine the origin and nature of the development of teacher expectations. That is, do teachers come into these various settings with a set of expectations that are then applied and incorporated into the existing school 
climate or are teacher expectations shaped by the context of the school? Determining the origin of expectations has important implications for teacher training as well as for the development of consistent expectations within a school. This latter notion is an important cornerstone of the recent movement in schoolwide positive behavior support models.

\section{REFERENCES}

Alvidrez, J., \& Weinstein, R. S. (1999). Early teacher perceptions and later student academic achievement. Journal of Educational Psychology, 91, 731-746.

Baer, D. M., Wolf, M. M., \& Risley, T. R. (1987). Some still-current dimensions of applied behavior analysis. Journal of Applied Behavior Analysis, 20, 313-327.

Baron, R. M., Tom, D. Y. H., \& Cooper, H. M. (1985). Social class, race, and teacher expectations. In J. B. Dusek (Ed.), Teacher expectancies (pp. 251-270). Hillsdale, NJ: Erlbaum.

Blyth, D. A., Simmons, R. G., \& Carlton-Ford, S. (1983). The adjustment of early adolescents to school transitions. Journal of Early Adolescence, 3, 105-120.

Brophy, J. (1986). Teacher influences on student achievement. American Psychologist, 41, 1069-1077.

Brophy, J. (1996). Teaching problem students. New York: Gilford.

Busk, P. L., \& Serlin, R. C. (1992). Meta-analysis for single-case research. In T. Kratochwill \& J. Levin (Eds.) Single case research design and analysis (pp. 187-212). Hillsdale, NJ: Erlbaum.

Cohen, J. (1988). Statistical power analysis for the behavioral sciences. New York: Academic Press.

Cook, B. G. (2004). Inclusive teachers' attitudes toward their students with disabilities: A replication and extension. Elementary School Journal, 104, 307-320.

Costello, E. J., Keeler, G. P., \& Angold, A. (2001). Poverty, race/ethnicity, and psychiatric disorder: A study of rural children. American Journal of Public Health, 91, 1494-1498.

Dusek, J. B., \& Joseph, G. (1983). The bases of teacher expectancies: A meta-analysis. Journal of Educational Psychology, 75, 327-346.

Eamon, M. K. (2001). The effects of poverty on children's socioemotional development: An ecological systems analysis. Social Work, 46, 256-266.

Edgar, E. (1992). A polymorphic tracking and intervention model for students with drop out or are at risk of dropping out of special education programs in Washington State (Final Report). Seattle University of Washington, Experimental Education Unit.

Fournier, R. (2002, January 9). Education overhaul signed. (Associated Press syndicated article). The Riverside Press Enterprise, pp. A1, A9.

Fuchs, D., Fuchs, L., Gilman, S., Reeder, P., Bahr, M., Fernstrom, P., et al. (1990). Prereferral intervention through teacher consultation: Mainstream assistance teams. Academic Therapy, 25, 262-276.

Gresham, F. M., Dolstra, L., Lambros, K. M., McLaughlin, V., \& Lane, K. L. (2000, November). Teacher expected model behavior profiles: Changes over time. Paper presented at the meeting of Teacher Educators for Children with Behavioral Disorders, Scottsdale, AZ.

Gresham, F. M., \& Elliott, S. N. (1990). Social Skills Rating System. Circle Pines, MN: American Guidance Service.

Hersh, R., \& Walker, H. M. (1983). Great expectations: Making schools effective for all students. Policy Studies Review, 2, 147-188.

Isakson, K., \& Jarvis, P. (1999). The adjustment of adolescents during the transition into high school: $\mathrm{A}$ short-term longitudinal study. Journal of Youth and Adolescence, 28, 1-26.

Kerr, M. M., \& Zigmond, N. (1986). What do high school teachers want? A study of expectations and standards. Education and Treatment of Children, 9, 239249.

Kleinbaum, D. G., Kupper, L. L., Muller, K. E., \& Nizam, A. (1998). Applied regression analysis and other multivariate methods (3rd ed.). Boston: PWS-Kent.

Lane, K. L., Givner, C. C., \& Pierson, M. R. (2004). Teacher expectations of student behavior: Social skills necessary for success in elementary school classrooms. Journal of Special Education, 38, 104-110.

Lane, K. L., Mahdavi, J. N., \& Borthwick-Duffy, S. A. (2003). Teacher perceptions of the prereferral intervention process: A call for assistance with school-based interventions. Preventing School Failure, 47, 148-155.

Lane, K. L., Pierson, M., \& Givner, C. C. (2003). Teacher expectations of student behavior: Which skills do elementary and secondary teachers deem necessary for success in the classroom? Education and Treatment of Children, 26, 413-430.

Lane, K. L., Pierson, M., \& Givner, C. C. (2004). Secondary teachers' views on social competence: Skills essential for success. Journal of Special Education, 38, 174-186. 
Lane, K. L., Wehby, J. H., Robertson, E. J., \& BartonArwood, S. (2005). Preparing for positive behavior support at the high school level: Implementation steps and outcomes. Manuscript in preparation.

Lipsey, M. W., \& Wilson, D. B. (2001). Practical metaanalysis. Thousand Oaks, CA: Sage.

National Center for Education Statistics. (2002). Discussion: Characteristics of the 100 largest public elementary and secondary school districts in the United States: 1999-2000, Table A. Retrieved September 1, 2004, from http://nces.ed.gov/pubs2001/100_largest/ discussion.asp\#tableA

National Education Association (April 28, 2004). Are male teachers on the road to extinction? Retrieved August 18, 2004, from http://www.nea.org/newsreleases/ 2004/nr040428.html

No Child Left Behind Act of 2001, Pub. L. No. 107110,115 Stat. 1425 (2001).

O'Shaughnessy, T., Lane, K. L., Gresham, F. M., \& Beebe-Frankenberger M. (2002). Students with or atrisk for learning and emotional-behavioral difficulties: An integrated system of prevention and intervention. In K. L. Lane, F. M. Gresham, \& T. E. O'Shaughnessy (Eds.), Interventions for children with or at risk for emotional and behavioral disorders (pp. 3-17). Boston: Allyn \& Bacon.

Seidman, E., Allen, L., Mitchell, C., \& Feinman, J. (1994). The impact of school transitions in early adolescence on the self-system and perceived social context of poor urban youth. Child Development, 65, 507-522.

Sulzer-Azaroff, B., \& Mayer, G. R. (1991). Behavior analysis for lasting change. Harcourt Brace College Publishers.

Tennessee Department of Education. (2003). School System Report Card 2002: Metropolitan Nashville Public Schools. Retrieved September 1, 2004, from bttp://www.k-12.state.tn.us/rptcrd02/system. asp?sysno $=190$

Wagner, M., D'Amico, R., Marder, C., Newman, L., \& Blackorby, J. (1992). What happens next? Trends in postschool outcomes of youth with disabilities. Menlo Park, CA: SRI International.

Walker, H. M., Irvin, L. K., Noell, J., \& Singer, G. H. S. (1992). A construct score approach to the assessment of social competence: Rationale, technological considerations, and anticipated outcomes. Behavior Modification, 16, 448-474.

Walker, H. M., Ramsey, E., \& Gresham, F. M. (2004). Antisocial behavior in school: Evidence-based practices (2nd ed.). Belmont, CA: Wadsworth.

Walker, H. M., \& Rankin, R. (1983). Assessing the behavioral expectations and demands of less restrictive setting. School Psychology Review, 1, 274-284.

Yates, T. M., Egeland, B., \& Sroufe, L. A. (2003). Rethinking resilience: A developmental process perspective. In L. Suniya (Ed.), Resilience and vulnerability: Adaptation in the context of childhood adversities (pp. 243-266). New York: Cambridge University.

\section{ABOUT THE AUTHORS}

kathleen L. Lane (CEC TN Federation), Assistant Professor; Joseph h. WeHby (CEC TN Federation), Associate Professor; and CRISTY COOLEY, former Masters' Student, Peabody College of Vanderbịlt University, Nashville, Tennessee.

Correspondence concerning this article may be addressed to Kathleen Lynne Lane, Department of Special Education, Peabody College, Box 328, Vanderbilt University, Nașhville, TN 37203. (e-mail: Kathleen.lane@vanderbilt.edu)

Manuscript received September 2004; accepted December 2004. 
Copyright of Exceptional Children is the property of Council for Exceptional Children and its content may not be copied or emailed to multiple sites or posted to a listserv without the copyright holder's express written permission. However, users may print, download, or email articles for individual use. 